\title{
K. Subramanya Sastry and Thomas A. Zitter: Plant virus and viroid diseases in the tropics, volume 2: epidemiology and management (Springer, 2014, $489 \mathrm{pp}$, ISBN 978-94-007-7819-1)
}

\author{
V. Muniyappa ${ }^{1}$
}

Received: 23 November 2015 / Accepted: 26 December 2015/Published online: 18 January 2016

(C) Indian Virological Society 2016

Many of the world's most important food crops are grown in the tropics, either through use of true seed or vegetative propagative material. Almost all the crops are affected with virus and viroid diseases. In the present reference book the authors, K Subramanya Sastry and T. A. Zitter have provided latest and comprehensive information on epidemiology and management of important plant virus and viroid diseases. The epidemics caused by certain virus and viroid diseases are responsible for extensive economic losses.

The book is divided into two chapters. In Chapter 1, authors described the various physical and biological factors responsible for epiphytotics including weeds which are main sources of infection and foci of vectors breeding. Detailed aspects of virus and viroid survival and spread were discussed. Various aspects of disease forecasting, disease progress curves, spatial dynamics, mathematical modeling techniques, system analysis and simulation models are described.

An effective and applicable plant virus and viroid disease management strategy requires an accurate diagnosis. Extensive recently developed molecular techniques are discussed. In the Chapter 2, the book covered in more detail on the strategies of management of tropical virus and viroid diseases viz., the selection of virus free seed and propagules, certification schemes of crops having virus/ viroid transmission through seed and vegetative propagules, avoidance of sources of infection, cross protection in crop plants, vector control by insecticides and oils, biological control of vectors, avoidance of vectors, and role of repelling and attracting surfaces in vector control, barrier cropping, time of planting, use of resistant varieties and transgenic plants. Importance of quarantine in avoiding the introduction of new virus and viroid diseases through germplasm is discussed in detail. Finally the authors have pointed out the role of integrated approach in plant virus and viroid disease management by citing number of successful stories in different virus-host combinations.

Disease-free crops and plants are of great economic and social importance in feeding the world's population. Unless sustainability of the growth in food production is insured through continuous improvement in yields from the limited land by managing the economically important virus and viroid diseases, which helps in the substantial improvement in productivity throughout the world.

The book provides an effective and comprehensive information on epidemiology and management aspects of virus and viroid diseases in tropics which is well written by the authors, regarding present status and possible feature strategies in holistic plant virus/vorid disease management. It should find a well-deserved place in the laboratories of different institutions and universities engaged in teaching and research in plant pathology and plant virology. The authors, K. Subramanya Sastry and T. A. Zitter are deserved for compliments for bringing out this reference book.

\footnotetext{
V. Muniyappa

vmuniyappa@gmail.com

University of Agricultural Sciences, Bengaluru, India
} 